\title{
Identification of calcium-binding proteins associated with the human sperm plasma membrane
}

\author{
Soren Naaby-Hansen ${ }^{1 *}$, Alan Diekman ${ }^{2}$, Jagathpala Shetty ${ }^{3}$, Charles J Flickinger ${ }^{3}$, Anne Westbrook ${ }^{4}$, John C Herr ${ }^{3^{*}}$
}

\begin{abstract}
Background: The precise composition of the human sperm plasma membrane, the molecular interactions that define domain specific functions, and the regulation of membrane associated proteins during the capacitation process, still remain to be fully understood. Here, we investigated the repertoire of calcium-regulated proteins associated with the human sperm plasma membrane.
\end{abstract}

Methods: Surface specific radioiodination was combined with two-dimensional gel electrophoresis, a 45Ca-overlay assay, computer assisted image analysis and mass spectrometry to identify calcium-binding proteins exposed on the human sperm surface.

Results: Nine acidic 45Ca-binding sperm proteins were excised from stained preparative 2D gels and identified by mass spectrometry. Five of the calcium binding proteins; HSPA2 (HSP70-1), HSPA5 (Bip), HYOU1 (ORP150), serum amyloid P-component (SAP) and protein kinase $\mathrm{C}$ substrate $80 \mathrm{~K}-\mathrm{H}(80 \mathrm{~K}-\mathrm{H})$ were found to be accessible to lodoBead catalyzed 1251-labelling on the surface of intact human sperm. Agglutination and immunofluorescence analysis confirmed that SAP is situated on the plasma membrane of intact, motile sperm as well as permeabilized cells. Western blot analysis showed increased phosphorylation of human sperm 80K-H protein following in vitro capacitation. This is the first demonstration of the $80 \mathrm{~K}-\mathrm{H}$ protein in a mammalian sperm.

Conclusion: The presence of SAP on the surface of mature sperm implies that SAP has a physiological role in reproduction, which is thought to be in the removal of spermatozoa from the female genital tract via phagocytosis. Since 80K-H is a Ca2+-sensor recently implicated in the regulation of both inositol 1,4,5-trisphosphate receptor and transient receptor potential (TRP) cation channel activities, its detection in sperm represents the first direct signaling link between PKC and store-operated calcium channels identified in human sperm.

\section{Background}

The composition and regulation of the plasma membrane (PM) of mammalian sperm have been subjects of numerous studies, which have facilitated the identification and characterization of a variety of gamete surface molecules. The study of the sperm surface is complicated, however, by the organization of the plasma membrane into several distinctive domains, each with its own composition and function, by its complement of unique testis-specific proteins, which may be auto or iso-antigenic in males and females, and by the addition of secretory proteins

\footnotetext{
* Correspondence: sonh@rn.dk; jch7k@cms.mail.virginia.edu

'Department of Clinical Immunology, Aalborg Sygehus, Århus University

Hospital, Aalborg, Denmark

${ }^{3}$ Department of Cell Biology, University of Virginia, Charlottesville, VA, USA
}

originating in the male sex accessory glands. As a consequence, the precise composition of the sperm surface, the molecular interactions that define domain specific functions, and the changes induced during the capacitation process, still remain to be fully elucidated.

Among physiologically important sperm surface molecules, the plasma membrane receptor(s) that mediates zona pellucida (ZP)-binding has not been unequivocally identified $[1,2]$, and the receptor-induced signaling cascade that culminates in acrosomal exocytosis remains to be fully elucidated. Calcium influx, however, is an absolute requirement for physiological induction of the acrosome reaction (AR) in all mammalian sperm [3]. ZPbinding generates a biphasic calcium response in sperm, which is currently thought to involve at least three 
separate, yet sequentially linked, $\mathrm{Ca}^{2+}$ channels $[2,4]$. Activation of the putative ZP-receptor leads to a transient influx of calcium through $\mathrm{T}$-type voltage-dependent calcium channels in the plasma membrane that are thought to be released from inactivation by the capacitation-induced hyperpolarization of the membrane potential [5]. This brief $(<500 \mathrm{~ms})$ initial elevation of $\left[\mathrm{Ca}^{2+}\right]_{\mathrm{i}}$ to micromolar levels activates the $\mathrm{Ca}^{2+}$-sensitive phospholipase PLC $\delta$, causing the generation of diacylglycerol (DAG) and inositol 1,4,5-triphosphate (IP ${ }_{3}$ ), and consumption of the plasma membrane positioned substrate phosphatidylinositol biphosphate $\left(\mathrm{PIP}_{2}\right)[4,6]$. The increased production of $\mathrm{IP}_{3}$ leads to the emptying of $\mathrm{IP}_{3}$-receptor regulated intracellular $\mathrm{Ca}^{2+}$-stores situated in the acrosome $[7,8]$ and in membrane bounded calreticulin containing vesicles localized to the post-acrosomal region of human sperm [9]. Similar to what happens in somatic cells, the depletion of $\mathrm{Ca}^{2+}$ from internal stores is thought to activate store-operated channels (SOC) in the sperm plasma membrane causing a sustained elevation in $\left[\mathrm{Ca}^{2+}\right]_{i}[7,10]$. Increases in calcium, cAMP and small $\mathrm{G}$ protein activities act together to set in motion the SNARE machinery (soluble N-ethylmaleimide-sensitive factor attachment protein receptor), which is required for the fusion between the outer acrosomal membrane and the overlying plasma membrane [4].

Thus, one approach to understanding changes in the gametes that take place before and during fertilization is to study the cellular constituents of the calcium signaling pathways and their functions in sperm. In the present study we have combined a ${ }^{45} \mathrm{Ca}$-overlay assay with vectorial radiolabelling and mass spectrometry analysis, to identify calcium-binding proteins situated on the surface of freshly ejaculated human sperm. Nine calciumbinding 2D gel protein spots were detected on Coomassie stained preparative gels by computer-aided image analysis and were identified by mass spectrometry: CABYR, calreticulin, tubulin, calmodulin, HYOU1, HSPA5, HSPA2, serum amyloid P-component (SAP), and $80 \mathrm{~K}-\mathrm{H}$. The latter five were found to be accessible to Iodo-Bead catalyzed ${ }^{125}$ I-labelling of intact, motile sperm and therefore were considered to be on the sperm surface. Members of four different heat shock protein families, including HYOU1, HSPA2 and HSPA5, have previously been detected on the surface of swimup harvested human sperm [11], and the heat shock proteins have been amply studied in other contexts, so attention was focused on SAP and $80 \mathrm{~K}-\mathrm{H}$. SAP is present in human testis and on the surface of mature sperm from healthy young men, suggesting that it has a physiological role in reproduction [12]. On the other hand, this is the first detection of the $\mathrm{Ca}^{2+}$ sensor $80 \mathrm{~K}$ -
$\mathrm{H}$ in mammalian sperm, where it may be a link between PKC and store-operated calcium channels.

\section{Methods}

\section{Preparation and labelling of human sperm}

Semen specimens were obtained from normal, healthy young men by masturbation. Only ejaculates with normal semen parameters (WHO criteria) were used in this study. Individual semen samples from five selected donors were allowed to liquify at room temperature (normally for $1 \mathrm{~h}$, range 0.5 to $3 \mathrm{~h}$ ) before the motile sperm were separated from seminal plasma, immature germ cells and non-sperm cells by the swim-up method [13]. All samples were obtained under informed consent using forms approved by the University of Virginia Human Investigation Committee. In some experiments the harvest was concentrated by density gradient centrifugation employing a discontinuous 55\%/80\% Percoll gradient, and was then resuspended in human tubal fluid (Irvine, Santa Ana, CA) containing human serum albumin $(30 \mathrm{mg} / \mathrm{ml})$ and $100 \mu \mathrm{M}$ progesterone. Capacitation was achieved by incubating the samples at $37^{\circ} \mathrm{C}$ in $5 \% \mathrm{CO}_{2}$. Samples were removed at various time points and isolated by centrifugation. Control samples of Percoll concentrated swim-up harvested sperm were removed and snap frozen prior to in vitro capacitation. Iodo-Bead (Pierce) catalyzed ${ }^{125}$ I-labelling of Percoll concentrated swim-up harvested sperm was performed as previously described [14].

Electrophoresis and analysis of spermatozoa proteins Purified sperm were solubilized in a lysis buffer containing: 2\% (v/v) NP-40; $8.8 \mathrm{M}$ urea; $100 \mathrm{mM} \mathrm{DTT;} \%$ (v/ v) ampholines $\mathrm{pH}$ 3.5-10; and the protease inhibitors 2 $\mathrm{mM}$ PMSF, $3 \mathrm{mg} / \mathrm{ml}$ TLCK, $1.46 \mathrm{mM}$ pepstatin A and $2.1 \mathrm{mM}$ leupeptin. $5 \times 10^{8}$ cells per ml were solubilized by constant shaking at $4^{\circ} \mathrm{C}$ for $60 \mathrm{~min}$. Insoluble material was removed by centrifugation at $10,000 \times \mathrm{g}$ for 2 min, and the supernatant used for first dimension electrophoresis. Protein concentrations were determined by using the bicinchoninic acid method (Pierce, Rockford, IL), employing bovine serum albumin as the standard.

Analytical two-dimensional gel electrophoresis was performed as previously described [14]. Preparative twodimensional gel electrophoresis in large format gels (23 $\times 23 \mathrm{~cm}$ ) was performed in an 'Investigator 2-D Electrophoresis System' (Genomic Solution, UK), employing the following ampholine (Pharmacia) composition: 20\% pH 5-7, 20\% pH 7-9 and 60\% pH 3.5-10.

Computerized pattern analysis and densitometry of autoradiograms and stained gels and membranes were performed employing the 2D Analyzer software (BioImage 2000). All radiolabeling experiments were 
replicated at least four times. Protein targets that had been identified by image comparison were carefully excised from Coomassie stained preparative 2-D gels, subjected to in-gel trypsinization, and analysed by LCelectrospray-tandem mass spectrometry [15].

Electrotransfer to PVDF membranes $(0.2 \mu \mathrm{m}$ pore size, Pierce) was carried out as previously described [16] using the transfer buffer composition of Matsudaira [17] (10 mM 3- [cyclohexylamino]-1-propanesulfonic acid, $10 \%$ methanol, $\mathrm{pH} 11$ ). PVDF immobilized proteins were visualized by staining the membrane in a solution containing 0.1\% Coomassie R250, 40\% methanol and $0.1 \%$ acetic acid for one minute, followed by destaining in a solution of $10 \%$ acetic acid and $50 \%$ methanol for 3 $\times 3$ minutes. The center of each selected Coomassie stained spot was carefully cut from the PVDF membrane and microsequenced by Edman degradation.

Calcium binding proteins were detected using a ${ }^{45} \mathrm{Ca}$ overlay assay modified from that described by Maruyama and colleagues [18]. The use of PVDF and the employment of phospho-imaging detection increased the signal to noise ratio compared to that achieved with NC-paper and X-ray films [9]. Some of the PVDF membranes were subsequently stained with Coomassie blue to localize the calcium binding proteins within the global pattern of 2DE separated protein species, while other membranes were used for western blot analysis.

A 1:2500 dilution of the anti-phosphotyrosine monoclonal antibody RC-20 (Transduction Laboratories) was used in western blots, while rabbit antiserum against SAP was used in a 1:2000 dilution. In some experiments secondary antibodies were employed alone as a control. Immunostaining was preceded by gold colloid staining of the NC-membrane of other blots to localize individual antigens within the global pattern of sperm proteins.

\section{Immunofluorescence staining of human spermatozoa}

For immunofluorescence studies of non-permeabilized motile cells, fresh human spermatozoa were harvested over a discontinuous 55\%/80\% Percoll gradient and subsequently washed three times with Ham's F-10 medium. The sperm were counted using a hemocytometer and diluted to a concentration of $1 \times 10^{6} \mathrm{sperm} / \mathrm{ml}$, and incubated with a rabbit antiserum against human SAP for $2 \mathrm{~h}$ (1:400 dilution), while the secondary antibody, a goat anti-rabbit IgG TRITC conjugate (Jackson ImmunoResearch), was applied at a 1:200 dilution for $1 \mathrm{~h}$ at $37^{\circ} \mathrm{C}$. DAPI II was utilized to stain the sperm DNA.

For immunofluorescent staining of permeabilized sperm, the Percoll harvested, washed spermatozoa were air dried and permeabilized with methanol for $10 \mathrm{~min}$ utes. The sperm were treated with $10 \%$ normal goat serum for $1 \mathrm{~h}$ at $22^{\circ} \mathrm{C}$ and incubated with either rabbit antiserum against human SAP (dilution 1:100) followed by the secondary antibody, a goat anti-rabbit IgG FITC conjugate (Jackson ImmunoResearch), or the secondary antibody alone for $1 \mathrm{~h}$ at $22^{\circ} \mathrm{C}$. The slides were washed and mounted with Slow-Fade antifade reagent (Molecular Probes, Eugene, OR) containing DAPI. Images were captured using a Zeiss Axioplan2 microscope (Carl Zeiss Inc., Thornwood, NY).

\section{Sperm agglutination assay}

The standard slide agglutination assay was performed as previously described [19]. Human semen samples were liquefied at room temperature. One part of semen diluted to $40 \times 10^{6} \mathrm{sperm} / \mathrm{ml}$ in Ham's F-10 medium was gently mixed with one part of anti-SAP polyclonal antiserum diluted 1:5 in Ham's F-10 medium. Ham's F10 alone was included as a negative control. A sperm agglutinating monoclonal antibody was utilized as a positive control [19]. Twenty microliters of each mixture were placed on a hemocytometer with a coverslip. Sperm agglutination was observed and recorded with differential interference contrast microscopy (DIC) using a Zeiss Axioplan microscope (Carl Zeiss, Inc., Thornwood, NY) equipped with a digital camera.

\section{Results}

Progressively motile human spermatozoa were harvested by the swim-up method, and surface-accessible phenols were labelled by Iodo-Bead catalyzed, electrophilic addition of cationic ${ }^{125}$ I [14]. After being removed from the Iodo-Beads the cells were subjected to Percoll density gradient centrifugation and washed three times with Ham's F-10 medium, to ensure that only proteins tightly bound to the plasma membrane were included in the study. Slightly more than one hundred radiolabelled protein spots with MW between 5 and $200 \mathrm{kDa}$ were detected by autoradiography after IEF/PAGE $(3.0<\mathrm{pI}<$ 8.5) separation (Figure 1). The cytosolic protein valosincontaining protein (VCP) and calreticulin (CRT), which localize to intracellular vesicles in the neck of human sperm, and the cytoskeletal proteins tubulin and actin were not radioiodinated by the vectorial labelling procedure (indicated by dark rectangles in Figure 1). Conversely, angiotensin converting enzyme (ACE), previously demonstrated to be attached to the human sperm plasma membrane [20], the sperm specific GPIanchored surface hyaluronidase PH-20 [21], as well as known components of both somatic and gamete cell surfaces, including several members of the heat shock protein (HSP) family [11,22-25], were all consistently labelled with radioiodine (denoted by black arrows in Figure 1), indicating that the employed procedure labelled surface exposed species.

Calcium binding proteins (CBPs) of human sperm were identified by the modified ${ }^{45} \mathrm{Ca}$-overlay procedure [9]. More than a dozen proteins with molecular weights 


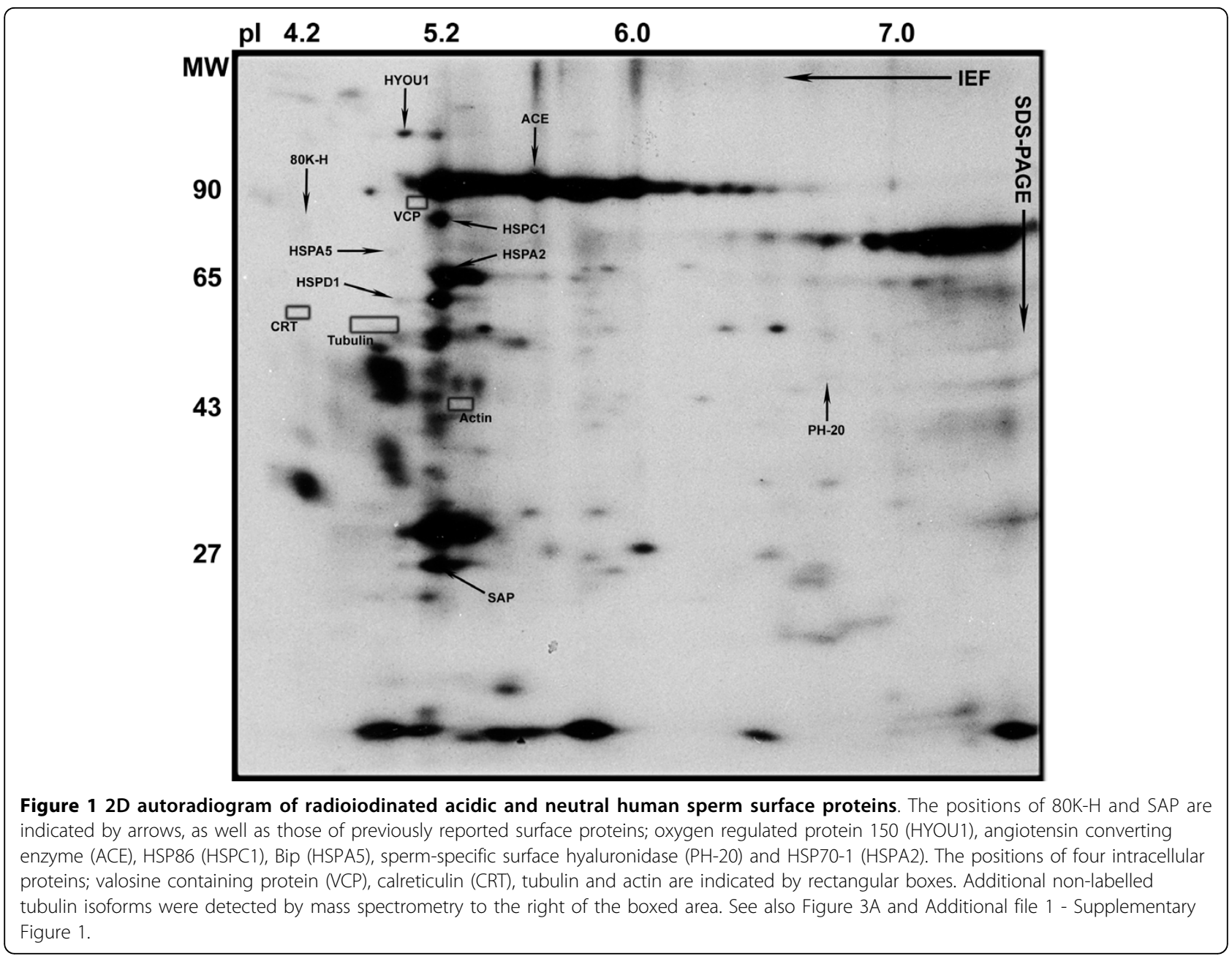

between 5 and $120 \mathrm{kDa}$, and isoelectric points ranging from 3 to 6 , were found to bind ${ }^{45} \mathrm{Ca}$ (Figures 2 and $3 \mathrm{C})$. Nine calcium-binding protein spots were carefully excised from complementary stained gels and PVDF membranes, and identified by mass spectrometry and/or Edman degradation analysis. The nine calcium-binding proteins thus identified in detergent/urea extracts of human sperm are given in Figure 2. The protein with the highest relative ${ }^{45} \mathrm{Ca}$-binding capacity was identified as calmodulin $(\mathrm{CaM})$, the major calcium-binding component of the mammalian sperm cytosol.

Computer comparison of $2 \mathrm{D}$ images of calcium-binding spots with images of proteins vectorially labelled with radioiodine and images of $2 \mathrm{D}$ gels where the proteins had been visualized by Coomassie or silver staining, allowed identification of calcium binding proteins exposed on the sperm surface. Five calcium binding proteins; HYOU1, HSPA5, HSPA2, SAP and 80K-H were found to be accessible to Iodo-Bead catalyzed radiolabelling. The three calcium binding HSP70 chaperones HYOU1, HSPA5 and HSPA2 were recently shown to be accessible to biotin labelling on the surface of motile human sperm [11].

The $80 \mathrm{kDa}$ calcium-binding surface protein migrating at a $\mathrm{pI}$ of 4 was identified as $80 \mathrm{~K}-\mathrm{H}$ (Figures 1,2 and 3 ), a phosphoprotein containing two calcium-binding helix-loop-helix structures. Radiolabelling of $80 \mathrm{~K}-\mathrm{H}$ was highly reproducible, although the amount of iodine-isotopes incorporated into the protein was sparse (see Figures 1 and 3A, and Additional file 1 - Supplementary Figure 1). $80 \mathrm{~K}-\mathrm{H}$ contains several potential threonine and tyrosine phosphorylation sites, and increased phosphorylation of the protein was observed following in vitro capacitation of human sperm (see Additional file 2 - Supplementary Figure 2). Efficient induction of in vitro capacitation was confirmed by the significant increase in tyrosine phosphorylation of CABYR, fibrous sheath protein 95 (FSP95, AKAP3) and valosin-containing protein/p97 (VCP) $[15,26]$. The capacitation-induced phosphorylation of $80 \mathrm{~K}-\mathrm{H}$ did not alter the protein's ${ }^{45} \mathrm{Ca}$ binding capacity (see Additional file 3 - Supplementary Figure 3). 


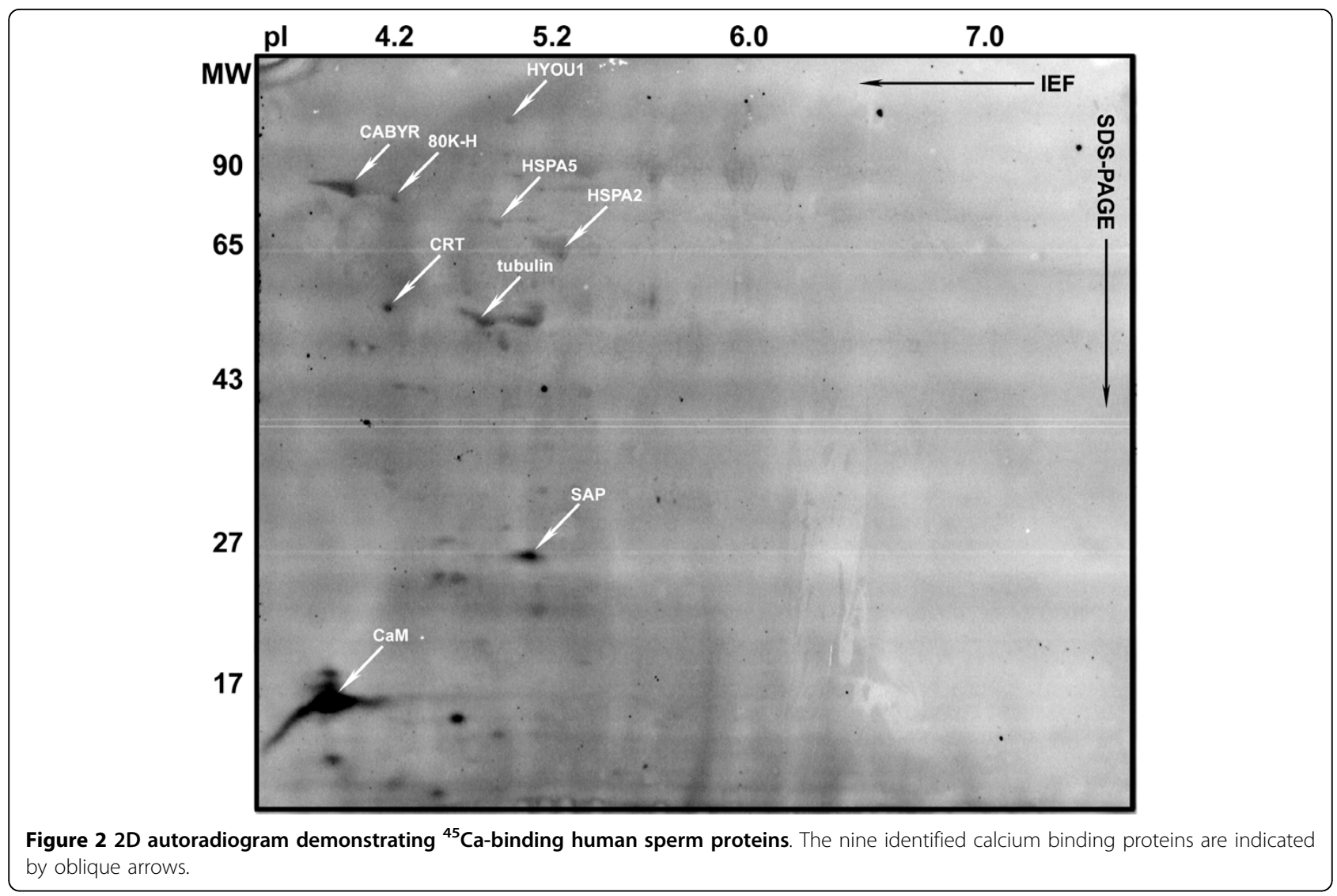

Densitometry of the autoradiograms showed that the abundant surface protein SAP (MW $26.5 \mathrm{kDa}, \mathrm{pI} 5.2$ ) accounts for more than six per cent of the ${ }^{45} \mathrm{Ca}$ binding capacity in the acidic and neutral $\mathrm{pH}$ range of the human sperm proteome, thus identifying SAP as the surface labelled constituent that binds relatively most ${ }^{45} \mathrm{Ca}$ in the overlay assay (Figures 1,2 and 3 ). Immunostaining of the PVDF membranes used for ${ }^{45} \mathrm{Ca}$ and ${ }^{125} \mathrm{I}$ autoradiography confirmed that the $26 \mathrm{kDa}$ surface labelled calcium-binding protein was SAP (Figure 3). In addition to the major ${ }^{45} \mathrm{Ca}$-binding form, a slightly more basic and at least one slightly more acidic form of the SAP antigen was revealed by the Western blot analysis (see Figure 3D and Additional file 4 - Supplementary Figure 4). SAP is a glycoprotein with a single N-glycosylation site, at Asn 32, which in the native protein contains a typical complex biantennary oligosaccharide chain [27]. Structural variants of SAP which lack one or both terminal sialic acid residues have been found in human plasma and urine [28], suggesting that the charge variants of human sperm SAP might be due to micro heterogeneity of the glycan structure.

Western blot analyses showed that the concentration of SAP in the medium from sperm incubated in the absence of calcium for $1 \mathrm{hr}$ at $37^{\circ} \mathrm{C}$ was several fold higher than that released from sperm incubated in the presence of $1.8 \mathrm{mM} \mathrm{CaCl}_{2}$ for a similar period (Figure $4 \mathrm{~A}$, left). Moreover, the addition of $5 \mathrm{mM}$ EDTA to fresh, motile human sperm induced a similar release of surface attached SAP within minutes (Figure 4A, right). However, less than $10 \%$ of the gamete's total SAP content was released by EDTA treatment (Figure 4B), indicating that the majority of SAP molecules are associated with the human sperm in a calcium-independent manner.

Immunofluorescence (IF) microscopy confirmed the presence of SAP on the surface of intact, viable human sperm (Figure 5). SAP was localized to the membrane overlying the neck, midpiece and tail regions of fresh, motile sperm (Figure 5A). The patches of SAP staining were confined to the proximal section of the principal piece in the majority of cases. IF staining of permeabilized fixed sperm revealed intracellular SAP antigen in the neck region of some human sperm (see Additional file 5 - Supplementary Figure 5).

Antiserum against SAP induced mixed agglutination of swim-up harvested human sperm in the standard slide agglutination assay (Figure $5 \mathrm{C}$ ), consistent with the broad distribution of the antigen observed by IF. The mixed agglutination pattern obtained with highly motile 

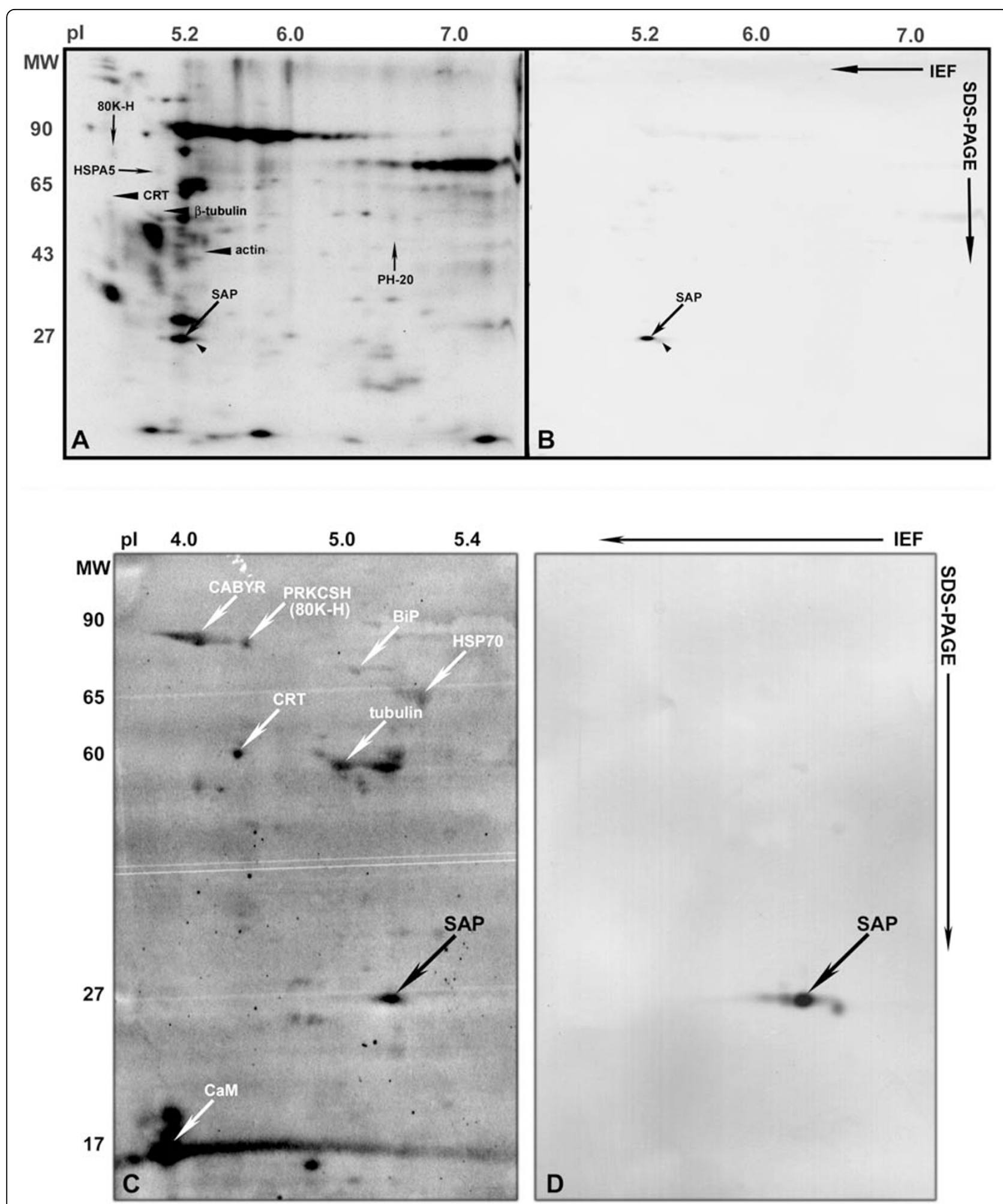

Figure 3 SAP is a ${ }^{45}$ Ca-binding protein exposed on the surface of human sperm. Immuno-staining of PVDF membranes used to detect radioiodinated surface proteins (A) and ${ }^{45} \mathrm{Ca}$-binding proteins $(C)$ by autoradiography confirmed that the $26.5 \mathrm{kDa}$ calcium binding surface protein with a pl of 5.2 (oblique downward arrows) is SAP (B \& D). 

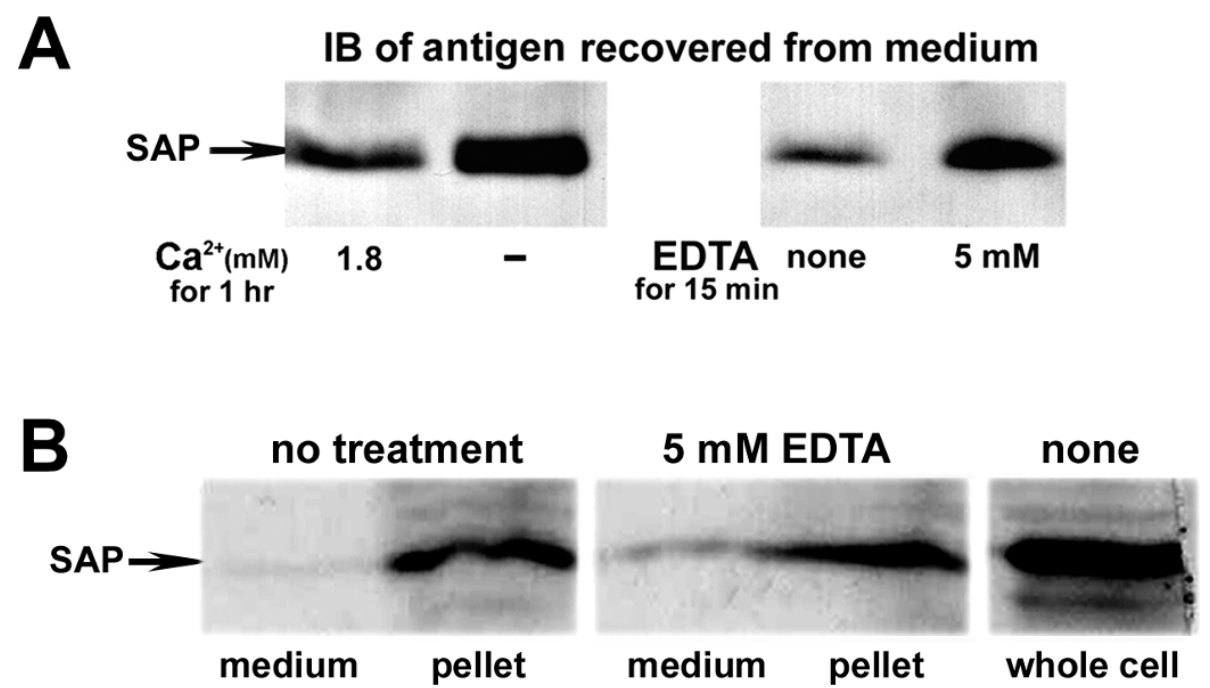

Figure 4 The majority of SAP molecules bind to the human sperm surface in a calcium-independent fashion. SAP is slowly released from the surface of washed, swim-up harvested human sperm when incubated in a $\mathrm{Ca}^{2+}$-free DMEM medium ( $\mathrm{A}$, left panel). The addition of 5 mM EDTA to the medium induced a similar strong discharge of surface bound SAP within minutes (A, right panel). However, most SAP antigens remained attached to the sperm, despite the removal of calcium from the medium (B).

cells implies that SAP is tightly bound to the plasma membrane overlying both the neck and tail regions of human sperm.

\section{Discussion}

Calcium-binding proteins detected by ${ }^{45} \mathrm{Ca}$-binding assay Five of the nine human sperm ${ }^{45} \mathrm{Ca}$-binding proteins identified in this study contain at least one calcium binding helix-loop-helix structure (EF-hand). This suggests that the EF-hand is either resistant to the denaturing effect of SDS to which the proteins are exposed to during the second dimension electrophoresis or that the domain is readily refolded during the subsequent mild electrotransfer, washing and blocking procedures. Both tubulin and HSP70 chaperones, which lack an EF-hand domain, have previously been shown to bind calcium [15,29-32], confirming the specificity of the ${ }^{45}$ Ca-overlay procedure employed in the present study.

Five of the calcium-binding proteins were found to be accessible for radioiodination on the surface of ejaculated human sperm: HYOU1, HSPA5, HSPA2, SAP, and $80 \mathrm{~K}-\mathrm{H}$. The three heat shock protein 70 family-members HYOU1, HSPA 5 and HSPA2 have previously been demonstrated on the surface of both the male $[11,24]$ and the female gamete [23]. Indeed, HSP70 antigens have been localized over the entire human sperm surface by immunofluorescence analysis [33].

Serum amyloid P-component (SAP) in association with spermatozoa

SAP has been localized to the human sperm surface by vectorial labelling, immunohistochemistry, and flow cytometry analysis $[15,12]$. The presence of SAP in the sperm-free seminal fluid from a vasectomized man suggested that SAP associates with the sperm membrane after the epididymal contents mix with secretions from the accessory glands [15]. However, SAP encoding mRNA was recently isolated from human testis, seminal vesicle and epididymis, indicating local synthesis of SAP in all three organs [12]. Moreover, SAP antigens were localized to the seminiferous tubules containing late spermatids by immunohistochemistry [12], and epididymal sperm and epithelial cells were also strongly positive for SAP, suggesting that at least some SAP antigen associates with the sperm membrane during the later stages of spermatogenesis and/or the epididymal maturation process [12].

The results from the experiments in which sperm were treated with EDTA indicate that most SAP molecules are attached to the human sperm membrane in a calcium-independent manner (Figure 4). SAP can bind to glycosaminoglycans and amyloid proteins in a calcium-independent manner [34,35], and it associates with microbial polysaccharides and extracellular matrix components through carbohydrate determinants, including heparin and 6-phosphorylated mannose. However, whether SAP's membrane attachment involves carbohydrate structures on the sperm surface, or occurs through interaction with other molecules situated in the outer leaflet of the sperm plasma membrane (e.g. phosphatidylethanolamine), remains to be determined.

SAP can activate the classical complement pathway via interaction with $\mathrm{C1q}$ [36], and complement components 

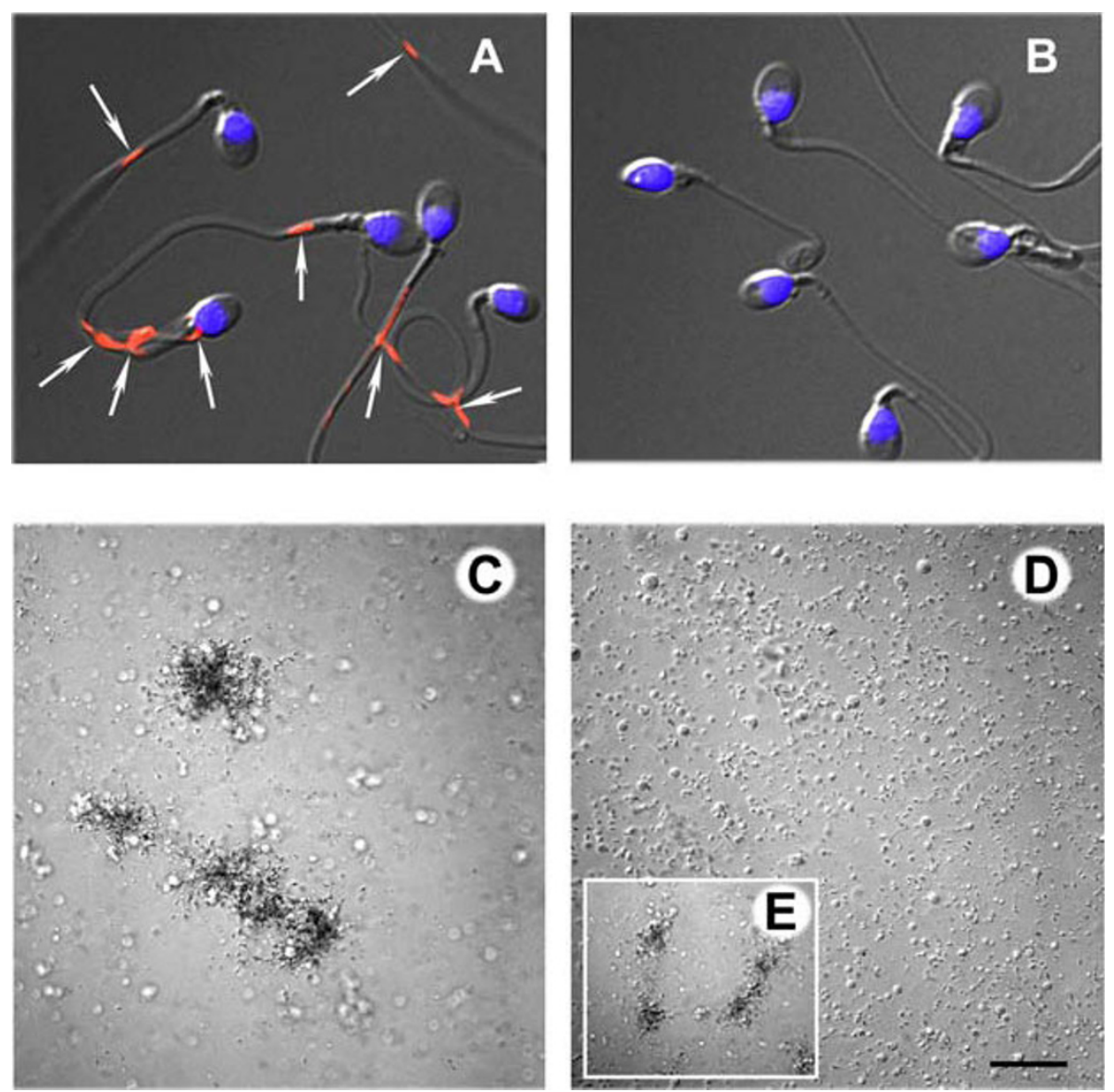

Figure 5 Demonstration of SAP on the surface of non-permeabilized, motile sperm. A: IF image demonstrating patches of SAP over the neck and tail regions of intact, motile human sperm (arrows). The nuclear DNA is stained blue with the DNA intercalating dye DAPI II. B: Secondary antibody alone control. C: Sperm agglutination floccules visualized by differential interface contrast microscopy. Antiserum against SAP agglutinated human sperm in a loose, tangled binding pattern, i.e. tail-to-tail, head-to-tail, and head to head. Round cells did not appear to be incorporated into the agglutination floccules. D: No antibody control without agglutination. Scale bar $=100 \mu \mathrm{m}$. E: A positive control with monoclonal antibody against CD52 induced strong agglutination.

on the head of acrosome reacted sperm have been suggested to facilitate sperm-egg binding via complement receptors on the egg surface [37]. However, SAP is an unlikely participant in such interactions as it mainly localizes to the neck and tail regions of intact, washed human sperm, and IF staining of permeabilized sperm failed to detect SAP antigens in the acrosome compartment (see Additional file 5 - Supplementary Figure 5).

Recent studies suggest that SAP can act as an opsonin [38-41], facilitating the uptake of apoptotic cells by direct interaction with the Fc $\gamma$ receptors on macrophages $[42,43]$. Binding of SAP and other members of the innate immune system to the asymmetric pattern of phospholipids found on apoptotic cells is also thought to have important immuno-modulatory effects on the ingesting phagocytes, triggering them to release antiinflammatory cytokines rather than to produce inflammatory cytokines, thereby collaborating T-cell suppression and the maintenance of tolerance [44-46].

SAP binding and stabilization of cellular debris and soluble immune complexes thus appear to facilitate their subsequent clearance by phagocytes $[47,48]$. In addition, SAP binds DNA and chromatin with high affinity and avidity [49], and it has been proposed that SAP's chaperone-like binding and stabilization of nuclear macromolecule antigens protect them from proteolysis and prevent subsequent spread of immunogenic degradation products [50]. Since mammalian spermatozoa are removed from the female genital tract via phagocytosis, mainly mediated by invading leukocytes and macrophages [51-53], these observations suggest the speculation that SAP participates in a molecular mechanism that facilitates the disposal of sperm remnants from the female genital tract, while at the same 
time ensuring that repetitive clearance of isoantigenic sperm and their cargo of super-coiled DNA by professional phagocytes occurs without triggering severe inflammatory or antinuclear autoimmune responses.

\section{K-H protein}

Several studies suggest that store-operated calcium channels in mammalian sperm belong to the transient receptor potential (TRP)-family of cation channels, whose members are closely related to the TRP gene expressed in Drosophilia photoreceptors [54]. Five members of the TRP channel family have been detected in mammalian sperm $[6,10,55]$, of which 4 localize to the head of the human sperm [4]. More important, maitotoxin, which induces $\mathrm{Ca}^{2+}$-uptake through its action on TRP channels, is the most potent inducer of the acrosome reaction in mouse sperm aside from ZP [56]. TRPC2 has been proposed to participate in the sustained $\mathrm{Ca}^{2+}$ influx triggered by ZP3 in mouse sperm [10], although it appears to be a pseudogene in humans [57,58]. TRPC channels can form heteromultimers [59], and it is likely that the store-operated $\mathrm{Ca}^{2+}$ entry pathway in sperm involves several family members, which can at least partly substitute for each others, as TRPC2 null mice are fertile $[60,61]$.

Several TRP channel regulating molecules have been identified, including STIM [62], junctate [63], $\mathrm{PIP}_{2}$ [64], enkurin [65], and 80K-H [66]. While enkurin and junctate previously have been detected in mouse sperm $[63,65]$, this is the first demonstration of the $80 \mathrm{~K}-\mathrm{H}$ protein in a mammalian sperm.

$80 \mathrm{~K}-\mathrm{H}$ is a multifunctional $\mathrm{Ca}^{2+}$-sensor originally identified as a substrate for PKC [67]. 80K-H has been associated with the regulation of intracellular signaling downstream of both the fibroblast growth factor receptor $[68,69]$ and the advanced glycosylation end products receptor [70], and it participates in the regulation of protein translocation [71]. 80K-H interacts with PKC and munc18c to induce glucose transporter 4 translocation to the plasma membrane [72]. A recent study suggests that $80 \mathrm{~K}-\mathrm{H}$ can regulate $\mathrm{IP}_{3}$-induced calcium release by interacting with the cytoplasmic tail of $\mathrm{IP}_{3}-$ receptors [73]. Finally, 80K-H has been shown to interact with and regulate the activity of the epithelial TRP channel V5 (TRPV5) [66]. The plasma membrane density and activity of TRPV 5 channels appear to be regulated via changes in their extracellular glycosylation status [74]. Processing of specific N-linked carbohydrate sidechains from the ectodomain of TRPV 5 channels is thought to entrap them in the plasma membrane, resulting in increased $\mathrm{Ca}^{2+}$ influx $[75,76]$. This is noteworthy, as $80 \mathrm{~K}-\mathrm{H}$ acts as the regulatory subunit of $\alpha$-glucosidase II, an N-linked glycan-processing enzyme [77,78].

Several studies have indicated a major role for PKC in the upregulation of cytosolic calcium levels prior to the
AR in human sperm [79-82], and it has been suggested that PKC participates in the opening of store-operated calcium channels in the sperm plasma membrane $[83,84]$. However the molecular mechanism by which PKC controls capacitative calcium entry has remained elusive.

Identification of the PKC substrate $80 \mathrm{~K}-\mathrm{H}$ in the human sperm proteome thus denotes the first putative effector molecule which directly links PKC to both the regulation of intracellular calcium stores and the opening of store-operated calcium channels in the sperm plasma membrane. The presence and phospho-regulation of sperm $80 \mathrm{~K}-\mathrm{H}$ support the notion that storeoperated calcium channels in human sperm belong to the TRP channel superfamily, and suggest that PKC might increase and sustain $\mathrm{Ca}^{2+}$-influx prior to the acrosome reaction through $80 \mathrm{~K}-\mathrm{H}$-mediated upregulation and stabilization of active TRP channels in the plasma membrane.

\section{Calcium binding proteins}

In this study a combination of surface protein labeling, two-dimensional gel electrophoresis, a ${ }^{45} \mathrm{Ca}$-overlay assay, and mass spectrometry led to the identification of five calcium binding proteins exposed on the surface of the human sperm plasma membrane. Although functionally interesting, none of the identified proteins possess a membrane spanning hydrophobic domain. Hydrophobic membrane proteins are known to be underrepresented on 2D gels [85], which may explain why no integral calcium-binding membrane proteins (e. g. TRP-family members) were detected by this experimental approach. One way this restriction can be circumvented is to use unidirectional gel electrophoresis (SDS-PAGE) separation of affinity purified membrane proteins [25] in future ${ }^{45} \mathrm{Ca}$ overlay studies of human sperm.

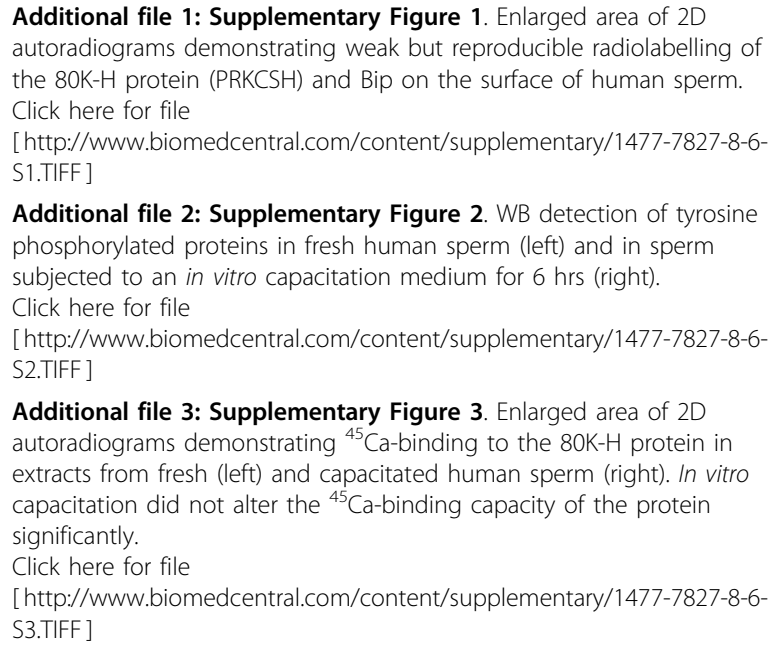

Additional file 3: Supplementary Figure 3. Enlarged area of 2D autoradiograms demonstrating ${ }^{45} \mathrm{Ca}$-binding to the $80 \mathrm{~K}-\mathrm{H}$ protein in extracts from fresh (left) and capacitated human sperm (right). In vitro capacitation did not alter the ${ }^{45}$ Ca-binding capacity of the protein significantly.

Click here for file

[http://www.biomedcentral.com/content/supplementary/1477-7827-8-6S3.TIFF ] 
Additional file 4: Supplementary Figure 4. Neutral and acidic human sperm proteins were separated by 2D gel electrophoresis (IEF/PAGE), and visualized by silver staining (A) or by colloidal gold staining following their transfer to a NC-membrane (B). Subsequent immuno-staining of the immobilized proteins with an antibody against SAP facilitated the identification of the different isoforms on silver stained gels. Click here for file

[http://www.biomedcentral.com/content/supplementary/1477-7827-8-6S4.TIFF]

Additional file 5: Supplementary Figure 5. Immunofluorescent detection of SAP in permeabilized human sperm. A: A punctuate immunofluorescence (green) was noted on the neck region of some sperm demonstrating the retention of SAP in methanol permeabilized sperm. The DAPI stained nuclear DNA is stained blue. B: Secondary antibody alone control.

Click here for file

[http://www.biomedcentral.com/content/supplementary/1477-7827-8-6S5.TIFF ]

\section{Acknowledgements}

We are very grateful to Dr. John Shannon for performing the Edman degradation analysis and to Dr. Nicholas E. Sherman for assistance with mass spectrometry analysis. This study was supported by U54 NIH HD29099 to $\mathrm{JCH}$, and by a grant from Karen Elise Jensens Foundation to $\mathrm{SNH}$.

\section{Author details}

'Department of Clinical Immunology, Aalborg Sygehus, Århus University Hospital, Aalborg, Denmark. ${ }^{2}$ Department of Biochemistry and Molecular Biology, University of Arkansas for Medical Sciences, Little Rock, Arkansas, USA. ${ }^{3}$ Department of Cell Biology, University of Virginia, Charlottesville, VA, USA. ${ }^{4}$ Telemedicine and Advanced Technology Research Center, Ft Detrick, MD, USA.

\section{Authors' contributions}

SNH performed design, analysis and reporting of study, acquisition of the data presented in Figures 1, 2, 3, 4A, and the Additional files supplementary material section. AD performed acquisition of the data presented in Figures $5 C-E$. JS performed acquisition of the data presented in Figure $4 \mathrm{~B}$ and Additional file 5 - Supplementary Figure 5. CJF performed revision of the manuscript. VAW performed acquisition of the data presented in Figures 5A-B. JCH organized the program and grant funding, and performed revision of the manuscript. All authors read and approved the final manuscript.

\section{Competing interests}

The authors declare that they have no competing interests.

Received: 18 September 2009

Accepted: 15 January 2010 Published: 15 January 2010

\section{References}

1. Jovine L, Darie CC, Litscher ES, Wassarman PM: Zona Pellucida Domain Proteins. Annu Rev Biochem 2005, 74:83-114.

2. Florman HM, Jungnickel MK, Sutton KA: Regulating the acrosome reaction. Int J Dev Biol 2008, 52(5-6):503-510

3. Darszon A, Beltrán C, Felix R, Nishigaki T, Treviño CL: Ion transport in sperm signaling. Dev Biol 2001, 240(1):1-14.

4. Darszon A, López-Martínez P, Acevedo JJ, Hernández-Cruz A, Treviño CL: Ttype Ca2+ channels in sperm function. Cell Calcium 2006, 40(2):241-252.

5. Arnoult C, Kazam IG, Visconti PE, Kopf GS, Villaz M, Florman HM: Control of the low voltage-activated calcium channel of mouse sperm by egg ZP3 and by membrane hyperpolarization during capacitation. PNAS 1999, 96:6757-6762

6. Felix R: Molecular physiology and pathology of Ca2+-conducting channels in the plasma membrane of mammalian sperm. Reproduction 2005, 129(3):251-262
7. OToole CM, Arnoult C, Darszon A, Steinhardt RA, Florman HM: $\mathrm{Ca}(2+)$ entry through store-operated channels in mouse sperm is initiated by egg ZP3 and drives the acrosome reaction. Mol Biol Cell 2000, 11(5):1571-1584.

8. De Blas G, Michaut M, Treviño CL, Tomes CN, Yunes R, Darszon A, Mayorga LS: The intraacrosomal calcium pool plays a direct role in acrosomal exocytosis. J Biol Chem 2002, 277(51):49326-49331.

9. Naaby-Hansen S, Wolkowicz M, Klotz K, Bush LA, Westbrook VA, Shibahara H, Shetty J, Coonrod SA, Reddi PP, Shannon J, Kinter M, Sherman NE, Fox J, Flickinger CJ, Herr JC: Co-localization of the inositol 1,4,5-triphosphate receptor and calreticulin in the equatorial segment and in membrane bounded vesicles in the cytoplasmic droplet of human spermatozoa. Mol Hum Reprod 2001, 7(10):923-933.

10. Jungnickel MK, Marrero H, Birnbaumer L, Lémos JR, Florman HM: Trp2 regulates entry of $\mathrm{Ca} 2+$ into mouse sperm triggered by egg $\mathrm{ZP}$. Nat Cell Biol 2001, 3(5):499-502.

11. Naaby-Hansen S, Herr JC: Heat shock proteins on the human sperm surface. J Reprod Immunol.

12. Malm J, Sonesson A, Hellman J, Bjartell A, Frohm B, Hillarp A: The pentraxin serum amyloid $\mathrm{P}$ component is found in the male genital tract and attached to spermatozoa. Int J Androl 2007, 31:508-517.

13. Bronson RA, Fusi F: Sperm-oolemmal interaction: role of the Arg-Gly-Asp (RGD) adhesion peptide. Fertil Steril 1990, 54(3):527-529.

14. Naaby-Hansen S, Flickinger CJ, Herr JC: Two-dimensional gel electrophoretic analysis of vectorially labeled surface proteins of human sperm. Biol Reprod 1997, 56:771-787.

15. Naaby-Hansen S, Mandal A, Wolkowicz MJ, Buer S, Westbrook VA, Shetty J, Coonrod SA, Klotz KL, Bush LA, Flickinger CF, Herr JC: CABYR, A Novel Calcium Binding Tyrosine-Phosphorylation Regulated Fibrous Sheath Protein Involved in Capacitation. Develop Biol 2002, 242:236-254.

16. Henzel WJ, Billeci TM, Stults JT, Wong SC, Grimley C, Watanabe C: Identifying proteins from two-dimensional gels by molecular mass searching of peptide fragments in protein sequence databases. PNAS 1993, 90(11):5011-5015.

17. Matsudaira P: Sequence from picomole quantities of proteins electroblotted onto polyvinylidene difluoride membranes. J Biol Chem 1987, 262(21):10035-10038.

18. Maruyama K, Mikawa T, Ebashi S: Detection of Calcium Binding Proteins by a ${ }^{45} \mathrm{Ca}$ Autoradiography on Nitrocellulose Membrane after Sodium Dodecyl Sulfate Gel Electrophoresis. J Biochem 1984, 95:511-519.

19. Diekman AB, Westbrook-Case VA, Naaby-Hansen S, Klotz KL, Flickinger CJ, Herr JC: Biochemical characterization of Spermatozoa Agglutination Antigen-1, a human spermatozoa antigen implicated in gamete interactions. Biol Reprod 1997, 56:771-787.

20. Shetty J, Diekman AB, Jayes FCL, Sherman N, Naaby-Hansen S, Flickinger CJ, Herr JC: Differential Extraction and Enrichment of Human Spermatozoa Surface Proteins in a Proteome: Identification of Immunocontraceptive Candidates. Electrophoresis 2001, 22:3053-3066.

21. Primakoff $P$, Myles DG: Penetration, adhesion, and fusion in mammalian sperm-egg interaction. Science 2002, 296:2183-2185.

22. Shin BK, Wang $H$, Yim AM, Naour FL, Brichory F, Jang JH, Zhao R, Puravs $E_{\text {, }}$ Tra J, Michael CW, Misek DE, Hanash SM: Global Profiling of the Cell Surface Proteome of Cancer Cells Uncovers an Abundance of Proteins with Chaperone Function. J Biol Chem 2003, 278:7607-7616.

23. Calvert ME, Digilio LC, Herr JC, Coonrod SA: Oolemmal proteomicsidentification of highly abundant heat shock proteins and molecular chaperones in the mature mouse egg and their localization on the plasma membrane. Reprod Biol Endocrinol 2003, 1:27-36.

24. Bohring C, Krause W: Characterization of spermatozoa surface antigens by antisperm antibodies and its influence on acrosomal exocytosis. Am $J$ Reprod Immunol 2003, 50:411-419.

25. Hastie C, Saxton M, Akpan A, Cramer R, Masters JR, Naaby-Hansen S: Combined affinity labelling and mass spectrometry analysis of differential cell surface protein expression in normal and prostate cancer cells. Oncogene 2005, 24(38):5905-5913.

26. Mandal A, Naaby-Hansen S, Wolkowicz MJ, Klotz K, Shetty J, Retief JD, Coonrod SA, Kinter M, Sherman N, Cesar F, Flickinger CF, Herr JC: FSP95, a testis specific $95 \mathrm{kDa}$ fibrous sheath antigen that undergoes tyrosine phosphorylation in capacitated human spermatozoa. Biol Reprod 1999, 61:1184-1197.

27. Tennent GA, Pepys MB: Glycobiology of the pentraxins. Biochem Soc Trans 1994, 22:74-79. 
28. Kiernan UA, Nedelkov D, Tubbs KA, Niederkofler EE, Nelson RW: Proteomic characterization of novel serum amyloid $\mathrm{P}$ component variants from human plasma and urine. Proteomics 2004, 4:1825-1829.

29. Sriram M, Osipiuk J, Freeman B, Morimoto R, Joachimiak A: Human Hsp70 molecular chaperone binds two calcium ions within the ATPase domain. Structure 1997, 5:403-414.

30. Serrano L, Valencia A, Caballero R, Avila J: Localization of the high affinity calcium-binding site on tubulin molecule. J Biol Chem 1986, 261:7076-7081.

31. Fong KC, Babitch JA, Anthony FA: Calcium binding to tubulin. Biochim Biophys Acta 1988, 952:13-19.

32. Kitao Y, Ozawa K, Miyazaki M, Tamatani M, Kobayashi T, Yanagi H, Okabe M, Ikawa M, Yamashima T, Stern DM, Hori O, Ogawa S: Expression of the endoplasmic reticulum molecular chaperone (ORP150) rescues hippocampal neurons from glutamate toxicity. J Clin Invest 2001, 108:1439-1450.

33. Miller D, Brough S, al-Harbi O: Characterization and cellular distribution of human spermatozoal heat shock proteins. Hum Reprod 1992, 7:637-645.

34. Danielsen B, Sørensen IJ, Nybo M, Nielsen EH, Kaplan B, Svehag SE: Calcium-dependent and -independent binding of the pentraxin serum amyloid $\mathrm{P}$ component to glycosaminoglycans and amyloid proteins: enhanced binding at slightly acid pH. Biochim Biophys Acta 1997, 1339:73-78.

35. Heegaard NH, He X, Blomberg LG: Binding of $\mathrm{Ca} 2+, \mathrm{Mg} 2+$, and heparin by human serum amyloid $\mathrm{P}$ component in affinity capillary electrophoresis. Electrophoresis 2006, 27:2609-2615

36. Hicks PS, Saunero-Nava L, Du Clos TW, Mold C: Serum amyloid P component binds to histones and activates the classical complement pathway. J Immunol 1992, 149:3689-3694.

37. Riley-Vargas RC, Lanzendorf S, Atkinson JP: Targeted and restricted complement activation on acrosome-reacted spermatozoa. J Clin Invest 2005, 115:1241-1249.

38. Familian A, Zwart B, Huisman HG, Rensink I, Roem D, Hordijk PL, Aarden LA Hack CE: Chromatin-Independent Binding of Serum Amyloid P Component to Apoptotic Cells. J Immunol 2001, 167:647-654.

39. Ciurana CLF, Hack CE: Competitive binding of pentraxins and IgM to newly exposed epitopes on late apoptotic cells. Cell Immunol 2006, 239:14-21.

40. Bijl M, Horst G, Bijzet J, Bootsma H, Limburg PC, Kallenberg CGM: Serum amyloid $\mathrm{P}$ component binds to late apoptotic cells and mediates their uptake by monocyte-derived macrophages. Arthritis \& Rheumatism 2003, 48(1):248-254

41. van Rossum AP, Fazzini $F$, Limburg PC, Manfredi $A A$, Rovere-Querini $P$, Mantovani A, Kallenberg CG: The prototypic tissue pentraxin PTX3, in contrast to the short pentraxin serum amyloid $\mathrm{P}$, inhibits phagocytosis of late apoptotic neutrophils by macrophages. Arthritis Rheum 2004, 50(8):2667-2674

42. Bharadwaj D, Mold C, Markham E, Du Clos TW: Serum Amyloid P Component Binds to Fc gamma Receptors and Opsonizes Particles for Phagocytosis. J Immunol 2001, 166:6735-6741.

43. Mold C, Baca R, Du Clos TW: Serum Amyloid P Component and CReactive Protein Opsonize Apoptotic Cells for Phagocytosis through Fcy Receptors. J Autoimmunity 2002, 19(3):147-154.

44. Kim SJ, Gershov D, Ma X, Brot N, Elkon KB: Opsonization of Apoptotic Cells and Its Effect on Macrophage and T Cell Immune Responses. Ann N Y Acad Sci 2003, 987:68-78.

45. Pittoni V, Valesini G: The clearance of apoptotic cells: implications for autoimmunity. Autoimmun Rev 2002, 1(3):154-161

46. Roos A, Xu W, Castellano G, Nauta AJ, Garred P, Daha MR, van Kooten C: A pivotal role for innate immunity in the clearance of apoptotic cells. Eur $J$ Immunol 2004, 34(4):921-929.

47. Gewurz $H$, Zhang $X-H$, Lint TF: Structure and function of the pentraxins. Curr Opin Immunol 1995, 7(1):54-64.

48. Brown MR, Anderson BE: Receptor-ligand interactions between serum amyloid $\mathrm{P}$ component and model soluble immune complexes. $J$ Immunol 1993, 151:2087-2095.

49. Pepys MB, Booth SE, Tennent GA, Butler PJG, Williams DG: Binding of pentraxins to different nuclear structures: $C$-reactive protein binds to small nuclear ribonucleoprotein particles, serum amyloid $\mathrm{P}$ component binds to chromatin and nucleoli. Clin Exp Immunol 1994, 97(1):152-157.
50. Bickerstaff MCM, Botto M, Hutchinson WL, Herbert J, Tennent GA, Bybee A Mitchell DA, Cook HT, Butler PJG, Walport MJ, Pepys MB: Serum amyloid P component controls chromatin degradation and prevents antinuclear autoimmunity. Nat Med 1999, 5:694-697.

51. Pandya IJ, Cohen J: The leukocytic reaction of the human uterine cervix to spermatozoa. Fertil Steril 1985, 43(3):417-421.

52. Phillips DM, Mahler S: Leukocyte emigration and migration in the vagina following mating in the rabbit. Anat Rec 1977, 189:45-56.

53. Bedford JM: Effect of environment on phagocytosis of rabbit spermatozoa. J Reprod Fertil 1965, 9:249-256.

54. Venkatachalam K, van Rossum DB, Patterson RL, Ma HT, Gill DL: The cellular and molecular basis of store-operated calcium entry. Nat Cell Biol 2002, 4(11):E263-272.

55. Treviño CL, Serrano CJ, Beltrán C, Felix R, Darszon A: Identification of mouse trp homologs and lipid rafts from spermatogenic cells and sperm. FEBS Lett 2001, 509(1):119-125.

56. Treviño CL, De la Vega-Beltrán JL, Nishigaki T, Felix R, Darszon A: Maitotoxin potently promotes $\mathrm{Ca} 2+$ influx in mouse spermatogenic cells and sperm, and induces the acrosome reaction. J Cell Physiol 2006, 206(2):449-456.

57. Zhu X, Jiang M, Peyton M, Boulay G, Hurst R, Stefani E, Birnbaumer L: trp, a novel mammalian gene family essential for agonist-activated capacitative Ca2+ entry. Cell 1996, 85(5):661-671.

58. Vannier B, Peyton M, Boulay G, Brown D, Qin N, Jiang M, Zhu X, Birnbaumer $\mathrm{L}$ : Mouse trp2, the homologue of the human $\operatorname{trpc2}$ pseudogene, encodes mTrp2, a store depletion-activated capacitative Ca2+ entry channel. PNAS 1999, 96(5):2060-2064.

59. Nilius $B$, Voets T: TRP channels: a TR(I)P through a world of multifunctional cation channels. Pflugers Arch 2005, 451(1):1-10.

60. Stowers L, Holy TE, Meister M, Dulac C, Koentges G: Loss of sex discrimination and male-male aggression in mice deficient for TRP2. Science 2002, 295(5559):1493-1500.

61. Leypold BG, Yu CR, Leinders-Zufall T, Kim MM, Zufall F, Axel R: Altered sexual and social behaviors in trp2 mutant mice. PNAS 2002, 99(9):6376-6381.

62. Zhang SL, Yu Y, Roos J, Kozak JA, Deerinck TJ, Ellisman MH, Stauderman KA Cahalan MD: STIM1 is a Ca2+ sensor that activates CRAC channels and migrates from the Ca2+ store to the plasma membrane. Nature 2005, 437(7060):902-9055.

63. Stamboulian S, Moutin MJ, Treves S, Pochon N, Grunwald D, Zorzato F, De Waard M, Ronjat M, Arnoult C: Junctate, an inositol 1,4,5-triphosphate receptor associated protein, is present in rodent sperm and binds TRPC2 and TRPC5 but not TRPC1 channels. Dev Biol 2005, 286(1):326-337.

64. Suh BC, Hille B: Regulation of ion channels by phosphatidylinositol 4,5bisphosphate. Curr Opin Neurobiol 2005, 15(3):370-378.

65. Sutton KA, Jungnickel MK, Wang Y, Cullen K, Lambert S, Florman HM: Enkurin is a novel calmodulin and TRPC channel binding protein in sperm. Dev Biol 2004, 274(2):426-435.

66. Gkika D, Mahieu F, Nilius B, Hoenderop JG, Bindels RJ: $80 \mathrm{~K}-\mathrm{H}$ as a new Ca2 + sensor regulating the activity of the epithelial $\mathrm{Ca} 2+$ channel transient receptor potential cation channel V5 (TRPV5). J Biol Chem 2004, 279(25):26351-26357.

67. Hirai M, Shimizu N: Purification of two distinct proteins of approximate Mr 80,000 from human epithelial cells and identification as proper substrates for protein kinase C. Biochem J 1990, 270(3):583-589.

68. Goh KC, Lim YP, Ong SH, Siak CB, Cao X, Tan YH, Guy GR: Identification of p90, a Prominent Tyrosine-phosphorylated Protein in Fibroblast Growth Factor-stimulated Cells, as 80K-H. J Biol Chem 1996, 271:5832-5838.

69. Kanai M, Göke M, Tsunekawa S, Podolsky DK: Signal transduction pathway of human fibroblast growth factor receptor 3. Identification of a novel 66-kDa phosphoprotein. J Biol Chem 1997, 272(10):6621-6628.

70. Li YM, Mitsuhashi T, Wojciechowicz D, Shimizu N, Li J, Stitt A, He C, Banerjee $\mathrm{D}$, Vlassara $\mathrm{H}$ : Molecular identity and cellular distribution of advanced glycation endproduct receptors: relationship of p60 to OST-48 and p90 to 80K-H membrane proteins. PNAS 1996, 93(20):11047-11052.

71. Brûlé S, Rabahi F, Faure R, Beckers JF, Silversides DW, Lussier JG: Vacuolar system-associated protein-60: a protein characterized from bovine granulosa and luteal cells that is associated with intracellular vesicles and related to human $80 \mathrm{~K}-\mathrm{H}$ and murine beta-glucosidase II. Biol Reprod 2000, 62(3):642-654 
72. Smithers NP, Hodgkinson CP, Cuttle M, Sale GJ: 80K-H acts as a signaling bridge in intact living cells between PKCzeta and the GLUT4 translocation regulator Munc18c. J Recept Signal Transduct Res 2008, 28(6):581-589.

73. Kawaai K, Hisatsune C, Kuroda Y, Mizutani A, Tashiro T, Mikoshiba K: 80K-H interacts with inositol 1,4,5-trisphosphate (IP3) receptors and regulates IP3-induced calcium release activity. J Biol Chem 2009, 284(1):372-380.

74. Schoeber JP, Hoenderop JG, Bindels RJ: Concerted action of associated proteins in the regulation of TRPV5 and TRPV6. Biochem Soc Trans 2007, 35(1):115-119.

75. Chang Q, Hoefs S, Kemp van der AW, Topala CN, Bindels RJ, Hoenderop JG: The beta-glucuronidase klotho hydrolyzes and activates the TRPV5 channel. Science 2005, 310(5747):490-493.

76. Cohen DM: Regulation of TRP channels by N-linked glycosylation. Semin Cell Dev Biol 2006, 17(6):630-637.

77. Trombetta ES, Simons JF, Helenius A: Endoplasmic reticulum glucosidase II is composed of a catalytic subunit, conserved from yeast to mammals, and a tightly bound noncatalytic HDEL-containing subunit. J Biol Chem 1996, 271(44):27509-27516.

78. Arendt CW, Ostergaard HL: Identification of the CD45-associated 116-kDa and $80-\mathrm{kDa}$ proteins as the alpha- and beta-subunits of alphaglucosidase II. J Biol Chem 1997, 272(20):13117-13125.

79. Breitbart H, Lax J, Rotem R, Naor Z: Role of protein kinase $\mathrm{C}$ in the acrosome reaction of mammalian spermatozoa. Biochem J 1992, 281(2):473-476.

80. O'Toole CM, Roldan ER, Fraser LR: Protein kinase C activation during progesterone-stimulated acrosomal exocytosis in human spermatozoa. Mol Hum Reprod 1996, 2(12):921-927.

81. Sousa M, Barros A, Mendoza C, Tesarik J: Effects of protein kinase C activation and inhibition on sperm-, thimerosal-, and ryanodine-induced calcium responses of human oocytes. Mol Hum Reprod 1996, 2(9):699-708.

82. Liu DY, Baker HW: Protein kinase C plays an important role in the human zona pellucida-induced acrosome reaction. Mol Hum Reprod 1997, 3(12):1037-1043.

83. Breitbart $\mathrm{H}$ : Intracellular calcium regulation in sperm capacitation and acrosomal reaction. Mol Cell Endocrinol 2002, 187(1-2):139-144.

84. Breitbart H: Signaling pathways in sperm capacitation and acrosome reaction. Cell Mol Biol (Noisy-le-grand) 2003, 49(3):321-327.

85. Naaby-Hansen S, Waterfield MD, Cramer R: Proteomics-Post-genomic cartography to understand cell function. Trends Pharmacol Sci 2001, 22(7):376-384

doi:10.1186/1477-7827-8-6

Cite this article as: Naaby-Hansen et al:: Identification of calcium-binding proteins associated with the human sperm plasma membrane.

Reproductive Biology and Endocrinology 2010 8:6.

Publish with BioMed Central and every scientist can read your work free of charge

"BioMed Central will be the most significant development for disseminating the results of biomedical research in our lifetime. "

Sir Paul Nurse, Cancer Research UK

Your research papers will be:

- available free of charge to the entire biomedical community

- peer reviewed and published immediately upon acceptance

- cited in PubMed and archived on PubMed Central

- yours - you keep the copyright 